\title{
PROSPEK USAHA PEMBUATAN PAKAN IKAN DENGAN TAMBAHAN Azolla microphylla DI DESA TEGAL REJO KECAMATAN BELITANG KABUPATEN OKU TIMUR
}

\author{
(Munsiarum)
}

\begin{abstract}
The objectives of this research are: (1) To know the production of fish feed (pellet) with additional Azolla microphylla in Tegal Rejo Village Belitang Sub-District, OKU Timur Regency, (2) Analyze the income on fish pellet production business with additional Azolla microphylla in Desa Tegal Rejo Belitang Sub-District, OKU Timur Regency, (3) Analyzing the development of fish meal business (pellet) with additional Azolla microphylla in Tegal Rejo Village Belitang Sub-District, OKU Timur Regency. This research was conducted in Tegal Rejo Village of OKU Timur Regency. The research has been conducted in Febuary 2015 until it is completed by purposive or purposive method, considering that in Tegal Rejo Village, OKU Timur Regency is one of the villages where there is a business of home fish production and the area has technical, economical and Ecological in the implementation of fish production business (home industry) and enough in the research criteria. This study found that in 2014 the business actors produce 9,790 $\mathrm{kg} /$ year with the price of $R p 5000 / \mathrm{kg}$ by giving revenue of $R p$ 48,950,000 with production cost $R p$ 7,425,000, thus giving income amounting to $R p-23,475,000$. In 2015 the business of making fish feed produces 7,150 kg / year with the selling price of $R p 6,500$ / $\mathrm{kg}$. Receipts obtained by business actors amounted to $R p$ $46,475,000$, with the use of production costs of $R p$ 26,193,250, thus earning revenue of $R p 20,281,750$. In 2016 the business of making fish feed with additional azollamicrophylla producing 7,920kg / year with the selling price of $R p 7.000 / \mathrm{kg}$ then the revenue is $R p 55.440 .000$, the use of production cost of $R p 30.324 .000$ then the income is Rp 25.116.000 and the making business Fish feed with additional Azolla microphylla in Tegal Rejo Village Belitang District, OKU Timur Regency is feasible to be developed. By fulfilling the criteria of NPV value Rp 16.867.875, IRR value of 31.86\%., And the value of Net B / C obtained 1.5.
\end{abstract}

Key Words : Fish cultivation, Plant Cultivation Azolla microphylla, Fish feed, and Income.

\section{PENDAHULUAN}

\section{A. Latar Belakang}

Ikan sebagai salah satu hasil perikanan merupakan salah satu bahan makanan yang tak asing lagi bagi masyarakat Indonesia. Bahan makanan ini merupakan sumber protein yang relatif murah, tetapi beberapa jenis di antaranya mempunyai nilai ekonomi yang cukup tinggi untuk diekspor. Salah satu kelemahan ikan sebagai bahan makanan ialah sifatnya yang mudah busuk setelah ditangkap dan mati. Oleh karena itu, ikan perlu ditangani dengan baik agar tetap dalam kondisi yang layak dikonsumsi oleh konsumen. Tidak kalah pentingnya adalah pemberian pakan pada ikan yang harus tersedia dan mencukupi kebutuhan baik kuantitas maupun kualitasnya. Untuk menjamin ketersediaan pakan ikan yang memadai maka perlu dilakukan usaha produksi pakan ikan buatan, sehingga kontinuitas produksi ikan akan berlangsung dengan lancar dan baik sampai pemanenan untuk selanjutnya disalurkan kepada konsumen (Masyamsir, 2001).

Pakan merupakan salah satu komponen input yang penting karena disamping dapat menentukan koefisien teknis budidaya seperti pertumbuhan (SGR), kelangsungan hidup (survival rate atau SR), konversi pakan (feed conversion ratio atau FCR), biomass dan waktu budidaya, pakan juga merupakan beban dalam lingkungan budidaya akibat limbah yang dihasilkan ikan, baik berasal dari pakan yang tidak termakan, tidak dicerna maupun limbah metabolisme. Salah satu kunci utama dalam pembuatan pakan yang tepat adalah formulasi pakan yang dapat memenuhi persyaratan kebutuhan nitrisi bagi ikan untuk pertumbuhan tetapi juga dapat mengurangi pencemaran yang diakibatkan tidak efisiennya penggunaan protein dalam pakan ikan (Asmina-tun, 2010). Semakin sempitnya perairan untuk budidaya ikan dan meningkatnya pencemaran air, maka pada masa mendatang budidaya konvensional harus diubah menjadi budidaya intensif (Sirakov \& Ivancheva, 2008).

Penggunaan pakan komersial dalam budidaya ikan air tawar mulai meningkat semenjak akhir tahun 1980 di Jawa Barat, seiring dengan berkembangnya kolam air deras dan Keramba Jaring Apung (KJA) di Waduk Cirata. Saat ini semua pembudidaya sangat fanatik terhadap pakan untuk peningkatan pertumbuh-an dan produksi. Hingga saat ini tercatat lebih dari 12 pabrik pakan tersebar di sentra produksi budidaya 
ikan di Jawa, Lampung dan Sumatera Utara. Hampir semua bahan baku pakan diimpor. Tepung ikan, tepung tulang dan tepung bungkil kedelai umumnya diguna-kan sebagai sumber protein hewani dan nabati. Pada tahun 2004-2009 impor tepung ikan meningkat dari 28.620.57 ton menjadi 47.518.97 ton (kenaikan sekitar 15,14\%) dengan rataan harga 916.12 US\$ per ton (KKP, 2010). Tepung ikan impor ini yang diduga menjadi penyebab tingginya harga pelet ikan di Indonesia. Harga pakan komersial saat ini berkisar Rp6.800- .800 per $\mathrm{kg}$, tergantung komposisi mutunya. Perma-salahan yang sering menjadi kendala yaitu penyediaan pakan buatan ini memerlukan biaya yang relatif tinggi, bahkan mencapai $60-70 \%$ dari komponen biaya produksi (Emma, 2006).

Penggunaan bahan baku lokal diharapkan dapat menurunkan biaya produksi pelet ikan Salah satu alternatif pengganti/pengurangan bahan baku pakan tepung ikan impor dengan menggunakan bahan baku berasal dari tepung ikan lokal yang diolah dari limbah industri perikanan, ikan rucah dan ikan yang sudah mengalami kemunduran mutu.

Menurut Dharmawan (2013), pellet ikan merupakan pakan buatan yang berasal dari campuran berbagai jenis bahan pakan yang kemudian dicetak dengan menggunakan mesin khusus hingga menjadi padatan tepung dengan bentuk silinder kecil. Ukuran pellet yang banyak digunakan dalam usaha budidaya ikan air tawar adalah berkisar antara ukuran 1- $7 \mathrm{~mm}$. Pellet dapat diberikan pada berbagai jenis ikan berupa karnivora, herbivora, dan omnivora yang berumur lebih dari 120 hari, sehingga ikan dapat tumbuh dengan cepat sesuai dengan keinginan peternak. Banyaknya jumlah pellet yang dapat dikonsumsi oleh seekor ikan secara umum berkisar $35 \%$ bobot tubuhnya atau $3-5 \%$ berat tubuhnya per hari, namun jumlah tersebut dapat berubah - ubah tergantung pada suhu lingkungannya.

Tabel 1. Acuan Bentuk dan Tipe Pakan (pellet) Buatan Untuk Budidaya.

\begin{tabular}{ccccc}
\hline No. & $\begin{array}{c}\text { Ukuran } \\
\text { Ikan } \\
(\mathrm{gr})\end{array}$ & $\begin{array}{c}\text { Tipe } \\
\text { Pakan }\end{array}$ & $\begin{array}{c}\text { Diameter } \\
\text { Pakan } \\
(\mathrm{mm})\end{array}$ & $\begin{array}{c}\text { Panjang } \\
\text { Pakan } \\
(\mathrm{mm})\end{array}$ \\
\hline 1. & $<0,35$ & Starter & 1,0 & - \\
2. & $2-5$ & Grower & 2,0 & - \\
3. & $5-12$ & Grower & 3,0 & $2-3$ \\
4. & $12-20$ & Finisher & 5,7 & $3-5$ \\
5. & $20-30$ & Finisher & 7,0 & $5-7$ \\
\hline
\end{tabular}

Sumber : Dharmawan, 2013.
Berdasarkan sumbernya, bahan baku yang sering digunakan oleh pembuatan pakan (pellet) tersebut terdiri dari tiga macam, berupa bahan hewani, nabati, dan tambahan. Bahan hewani berasal dari hewan seperti tepung ikan, tepung kerang, tepung daging, tepung tulang, tepung darah, dan tepung udang. Sedangkan bahan nabati diperoleh bungkil kedelai, bungkil kelapa, bungkil kacang tanah, tepung terigu, jagung, biji kapas, biji kapuk, dedak, ampas tahu, bekatul, dan bahan tambahan berupa tepung batu, tepung kapur, premix, garam, dan ragi sebagai sumber vitamin dan mineral (Gusrina, 2005).

Salah satu cara untuk mengurangi biaya pakan dengan menambahkan pakan alternatif. Salah satu bahan pakan alami yang dapat dijadikan pakan alternatif adalah Azolla microphylla selain mudah didapatkan di daerah persawahan dan sudah digunakan sebagai pakan tambahan oleh pembudidaya ikan di Jawa (Gunawan dkk, 2011).

Penambahan Azolla microphylla dalam pakan diharapkan mampu memenuhi kebutuhan protein pakan pada ikan. Azolla yang digunakan sebagai suplementasi bahan pakan kaya akan nutrisi dan selain tinggi protein yaitu sekitar 25$35 \%$, juga kaya asam amino esensial, vitamin (vitamin A, vitamin B12 dan beta karoten) juga mineral $(\mathrm{Ca}, \mathrm{P}, \mathrm{Fe}$, dan $\mathrm{Mg})$ serta kandungan growth promoter atau hormon pertumbuhan mampu meningkatkan laju pertumbuhan itik. Pada kondisi kering, Azolla mengandung 25-35\% protein, $10-15 \%$ mineral, dan $7-10 \%$ asam amino. Karbohidrat dan lemak dari Azolla juga rendah, sehingga sangat baik sebagai pakan (Handjani, 2000).

Azolla microphylla jenis tanaman air yang dapat tumbuh di mana saja. Pertumbuhannya yang sangat cepat yaitu hanya dalam waktu 3-4 hari dapat menjadi dua kali lipat dari jumlah semula, maka dianggap sebagai gulma. Artinya kedua bahan tersebut memiliki ketersediaan yang cukup banyak dan dapat sebagai bahan pakan alternatif. Kandungan yang dimiliki oleh Azolla microphylla berpotensi memenuhi kebutuhan protein pakan untuk meningkatkan bobot badan dan laju pertumbuhan. Oleh karena itu perlu dilakukan kajian mengenai interaksi level protein, level protein optimal untuk meningkatkan bobot badan dan laju pertumbuhan, serta pengaruh penggunaan Azolla microphylla terhadap bobot badan ikan (Handjani, 2006).

Kabupaten OKU Timur merupakan salah satu penghasil ikan patin terbesar di Sumatera Selatan dengan produksi pertahun lebih dari 30 
ton. Saat ini lanjutnya, para petani ikan patin mengalami kesulitan dalam pembuatan pakan. Untuk itu, dalam rangka pengembangan ikan patin kedepan, pihaknya akan melakukan pengadaan mesin pembuat pakan yang dibagikan kepada desa yang berpotensi dalam budidaya perikanan masyarakat diharapkan mampu dalam memproduksi pakan sebagai tambahan dalam usaha pembuatan pakan ikan (Santio, 2012).

Munculnya inovasi baru pada usaha pembuatan pakan ikan di Desa Tegal Rejo salah satu desa yang memiliki potensi dalam pembuatan pakan ikan (Pellet) dengan skala industri rumahan karena banyaknya usaha budidaya ikan air tawar yang memerlukan banyak pakan dalam meningkatkan produksi ikan sehingga desa tersebut mengembangkan usaha home industry pakan ikan berupa pellet dengan memanfaatkan limbah pertanian dari hasil penggilingan padi berupa dedak dan bekatul sebagai salah satu sumber bahan baku dalam pembuatan pellet ikan, dan memanfaatkan limbah pabrik ikan asin sebagai sumber proteinnya dengan tambahan Azolla microphylla sebagai penambahan protein dan suplementasi pada.

Jenis ikan yang dapat mengkonsumsi pakan tambahan azolla adalah komoditas ikan air tawar seperti ikan lele, nila, gurami, dan mujair. Permintaan pakan ikan berupa pellet relatif tinggi yakni berkisar antara 6 ton/bulan, hal tersebut dikarenakan pengusaha tersebut menjual pellet dengan harga rata - rata yang jauh lebih murah dari harga pabrik yaitu Rp 4.500/kg.

\section{B. Rumusan Masalah}

1. Bagaimana teknik pembuatan pakan ikan (pellet) dengan tambahan Azolla microphylla di Desa Tegal Rejo Kecamatan Belitang Kabupaten OKU Timur.

2. Berapa besar pendapatan pada usaha pembuatan pakan ikan (pellet) dengan tambahan Azolla microphylla di Desa Tegal Rejo Kecamatan Belitang Kabupaten OKU Timur.

3. Apakah usaha pembuatan pakan ikan (pellet) dengan tambahan Azolla microphylla di Desa Tegal Rejo Kecamatan Belitang Kabupaten OKU Timur layak untuk dikembangkan.

\section{Tujuan dan Kegunaan}

1. Mengetahui pembuatan pakan ikan (pellet) dengan tambahan Azolla microphylla di Desa Tegal Rejo Kecamatan Belitang Kabupaten OKU Timur.
2. Menganalisis pendapatan pada usaha pembuatan pakan ikan (pellet) dengan tambahan Azolla microphylla di Desa Tegal Rejo Kecamatan Belitang Kabupaten OKU Timur

3. Menganalisis pengembangan usaha pembuatan pakan ikan (pellet) dengan tambahan Azolla microphylla di Desa Tegal Rejo Kecamatan Belitang Kabupaten OKU Timur.

\section{Model Pendekatan}

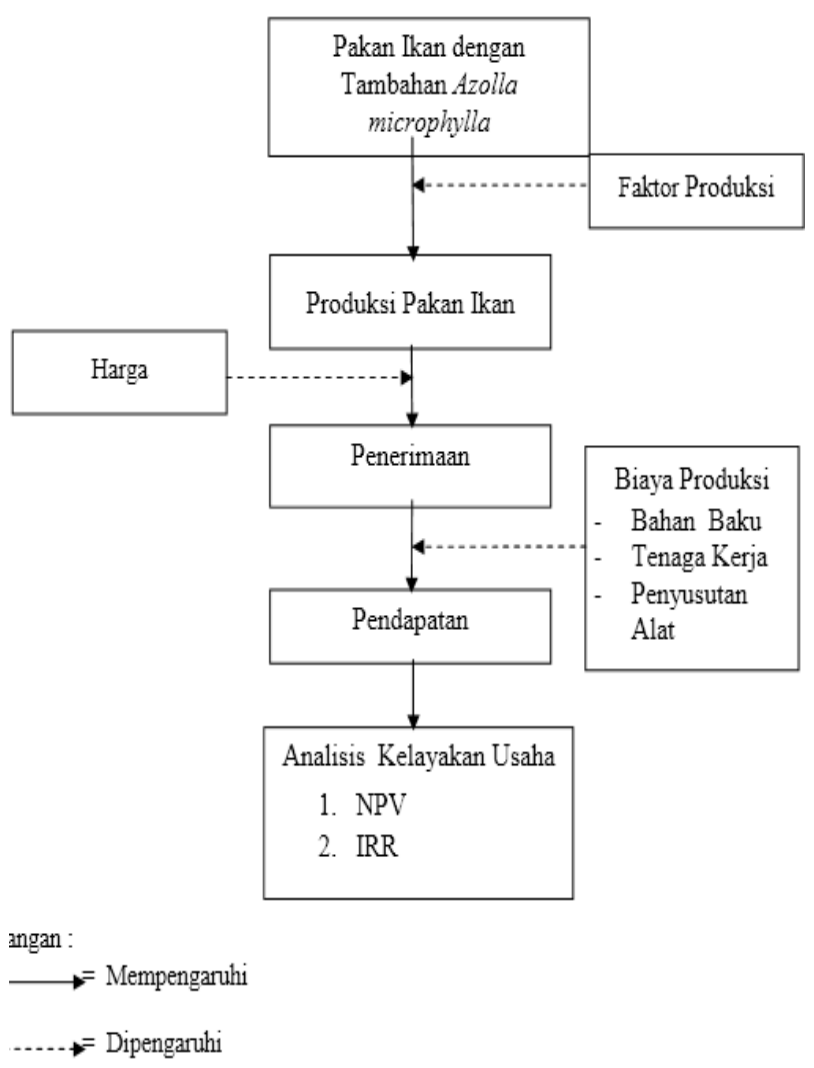

Gambar 1. Model pendekatan penelitian secara diagramatik

\section{METODOLOGI PENELITIAN}

\section{A. Tempat dan Waktu}

Penelitian ini telah dilaksanakan di Desa tegal Rejo Kabupaten OKU Timur. Penelitian telah dilaksanakan pada Bulan Febuari 2015 sampai dengan selesai.

\section{B. Metode Penelitian}

Metode yang digunakan dalam penelitian ini adalah metode purposive atau sengaja, dengan pertimbangan bahwa di Desa Tegal Rejo Kabupaten OKU Timur adalah salah satu desa yang terdapat usaha pembuatan pakan ikan (home 
industry) serta wilayah tersebut memiliki aspek teknis, ekonomis, dan ekologis dalam pelaksanaan usaha pembuatan pakan ikan (home industry) dan cukup dalam kriteria penelitian.

\section{Metode Penarikan Contoh}

Metode penarikan contoh yang digunakan dalam penelitian ini adalah studi kasus (case study). Menurut Nazir (2011) teknik penentuan sampel dengan studi kasus yaitu untuk meneliti status subjek penelitian yang berkenan dengan suatu fase spesifik atau khas dari keseluruhan personalitas. Peneliti ingin mempelajari secara intensif latar belakang serta interaksi lingkungan dari unit-unit sosial yang menjadi subjek. Tujuan studi kasus adalah untuk memberikan gambaran secara mendetail tentang latar belakang, sifat serta karakter yang khas dari kasus (individu), yang kemudian sifat khas itu akan dijadikan suatu hal yang bersifat umum.

Peneliti akan melaksanakan penelitian pada usaha pembuatan pakan ikan dengan tambahan azolla di Desa Tegal Rejo Kecamatan Belitang Kebupaten OKU Timur dengan tujuan untuk mengetahui potensi dari pembuatan pakan ikan (pellet) dengan tambahan Azolla microphylla yang belum diketahui oleh masyarakat secara luas.

\section{Metode Pengolahan Data}

Data yang diperoleh di lapangan dikelompokkan secara tabulasi lalu dianalisis secara matematis. Untuk menghitung biaya produksi pada usaha pembuatan pakan ikan dengan tambahan azolla, dapat menggunakan rumus matematis (Suratiyah, 2006) sebagi berikut :

$\mathrm{TC}=\mathrm{FC}+\mathrm{VC}$

Keterangan :

$\mathrm{TC}=$ Total Cost / Total Biaya Produksi (Rp/ Proses Produksi)

$\mathrm{FC}=$ Fixed Cost $/$ Biaya Tetap $(\mathrm{Rp} /$ Proses Produksi)

$\mathrm{VC}=$ Variable cost / Biaya Variabel (Rp/Proses Produksi)

Untuk menghitung penerimaan dapat menggunakan rumus matetamtis sebagai berikut :

$\mathrm{R}=\mathrm{P} \times \mathrm{Y}$

Keterangan :

$\mathrm{R}=$ Revenue / Penerimaan ( $\mathrm{Rp} /$ Proses Produksi)

$\mathrm{Y}=$ Yield $/$ Produksi (Rp/Proses Produksi)

$\mathrm{P}=$ Price / Harga ( $\mathrm{Rp} /$ Proses Produksi)

Dalam menghitung jumlah pendapatan dapat menggunakan rumus matetamtis sebagai berikut:
$\mathrm{I}=\mathrm{TR}-\mathrm{TC}$

Keterangan :

I = Income/Pendapatan (Rp/Proses Produksi)

$\mathrm{TR}=$ Total Revenue/Penerimaan $(\mathrm{Rp} /$ Proses Produksi)

$\mathrm{TC}=$ Total Cost $/$ Biaya Produksi $(\mathrm{Rp} /$ Proses Produksi)

Untuk menghitung kelayakan finansial pada usaha pembuatan pakan ikan dengan penambahan azollamicrophylla menggunakan rumus sebagai berikut ;

a. Menurut Ibrahim (2009), untuk menghitung tingkat investasi/tingkat penghasilan lebih

$$
\mathrm{NPV}=\sum_{\mathrm{i}=1}^{\mathrm{n}} \overline{\mathrm{B}}-\overline{\mathrm{C}}_{\mathrm{N}}
$$

Dimana :

$\mathrm{NB}=$ Net Benefit/Pendapatan Bersih

$\mathrm{C}=$ Biaya Investasi + Biaya Operasional

$\overline{\mathrm{B}}=$ Benefit Yang Telah Didiscount Faktor

$\overline{\mathrm{C}}=$ Biaya Yang Telah Didiscount Faktor

$\mathrm{i}=$ Discount Faktor/Tingkat Bunga

$\mathrm{n}=$ Tahun (Waktu)

Kaidah

NPV $>0$ (nol) $\rightarrow$ usaha layak (feasible) untuk dilaksanakan

$\mathrm{NPV}<0($ nol $) \rightarrow$ usaha tidak layak (feasible) untuk dilaksanakan

$\mathrm{NPV}=0($ nol $) \rightarrow$ usaha berada dalam keadaan BEP

b. Menurut Ibrahim (2009) untuk menghitung tingkat bunga yang berlaku kini

IRR $=i_{1}+\frac{\text { NPVP }}{\text { NPVP-NPWN }} X\left(i_{2}-i_{1}\right)$

Dimana

$i_{1} \quad$ : Discount Faktor Terendah

$\mathrm{i}_{2} \quad$ : Discount Faktor Tertinggi

NPVP : Net Persent Value Positive (Pendapatan Pada Tingkat Bunga Positif)

NPVN : Net Persent Value Negative (Pendapatan Pada Tingkat Bunga Negatif)

SOCC : Social Opportunity Cost of Capital (Tingkat Bunga Berlaku Kini 18\%)

Kaidah

IRR > SOCC maka usaha feasible/layak untuk di teruskan

IRR = SOCC maka usaha Break Efent Point/Impas

IRR < SOCC maka usaha usaha tidak feasible/Tidak Layak Diteruskan

c. Ibrahim Y (2009), untuk mengetahui tingkat kelayakan dalam pendapatan digunakan rumus sebagai berikut : 
Kaidah

$$
\text { NetB/C }=\frac{\sum \frac{(B-C)}{(1+i)^{t}}(+)}{\sum \frac{(B-C)}{(1+i)^{t}}(-)} .
$$

Net $B / C>0$, Maka usaha tersebut layak

Net $B / C<0$, Maka usaha tersebut tidak layak

Net $\mathrm{B} / \mathrm{C}=0$, Maka usaha tersebut impas.

\section{HASIL DAN PEMBAHASAN}

\section{A. Analisis Usaha Pembuatan Pakan Ikan dengan Azolla microphylla di Desa Tegal Rejo Kecamatan Belitang.}

\section{Analisis Biaya Produksi}

Biaya adalah pengorbanan sumber ekonomi yang diukur dalam satuan uang yang telah terjadi atau kemungkinan akan terjadi untuk mencapai tujuan tertentu). Biaya dalam kegiatan usahatani dikeluarkan oleh responden dengan tujuan untuk menghasilkan pendapatan yang tinggi dari usaha yang dikerjakan, dengan mengeluarkan biaya maka suatu usaha mengharapkan pendapatan yang setinggitingginya melalui peningkatan produksi.

Biaya tetap (Fixed Cost) Biaya yang relatif tetap jumlahnya dan harus dikeluarkan walaupun produk yang dihasilkan banyak atau sedikit. Biaya tidak tetap (Variable cost) biaya tidak tetap yang sifatnya berubah-ubah tergantung dari besar kecilnya produksi yang dihasilkan (Soekartawi, 2011). Hasil penelitian pembuatan pakan ikan dengan menggunakan tambahan azolla microphylla di Desa Tegal Rejo Kecamatan Belitang yang dikelompokkan ke dalam biaya tetap di antaranya adalah pembuatan bangunan dan pembelian peralatan. Analisa biaya tetap (biaya investasi) dihitung selama 3 tahun dari jalannya usaha penelitian pembuatan pakan ikan dengan menggunakan tambahan azolla microphylla dari tahun 2014 sampai dengan tahun 2016. Usaha pembuatan abon ayam dilakukan responden setiap bulan pada setiap tahunnya hanya bulan tertentu produsen tidak memproduksi pakan ikan. Produksi dilakukan minimal 4 kali proses setiap bulannya. Berikut adalah tabel penggunaan biaya tetap pada usaha penelitian pembuatan pakan ikan dengan menggunakan tambahan azolla microphylla.

Tabel 2.Biaya Tetap pada Usaha Penelitian Pembuatan Pakan Ikan dengan Menggunakan Tambahan Azolla microphylla.

\begin{tabular}{rrrrrr}
\hline & & \multicolumn{3}{c}{ Tahun } & \\
\cline { 2 - 4 } No & Biaya Investasi & \multicolumn{1}{c}{2013} & 2014 & 2015 & Jumlah \\
\hline 1. & Sewa Tempat & 30.000 .000 & - & - & 30.000 .000 \\
2. & Mesin Diesel & 5.275 .000 & - & - & 5.275 .000 \\
3. & Mesin Giling & 6.650 .000 & - & - & 6.650 .000 \\
4. & Ember & 32.000 & 40.000 & 40.000 & 112.000 \\
5. & Tanki Air Plastik & 1.145 .000 & - & - & 1.145 .000 \\
6. & Drum Plastik & 250.000 & - & - & 250.000 \\
7. Sapu Lantai & 17.500 & 18.000 & 20.000 & 55.500 \\
8. Jarum Jahit & 1.000 & 1.000 & 1.000 & 3.000 \\
9. & Timbangan & 650.000 & - & - & 650.000 \\
10. Lori & 350.000 & - & - & 350.000 \\
11. Skop & 45.000 & - & - & 45.000 \\
12. Gayung & 12.000 & 12.000 & 12.000 & 36.000 \\
13. Terpal & 185.000 & 180.000 & 180.000 & 545.000 \\
\hline Total Biaya Investasi & 44.612 .500 & 251.000 & 253.000 & 45.116 .500 \\
\hline
\end{tabular}

Sumber: Olahan Data Primer, 2015.

Berdasarkan tabel di atas bahwa penggunaan biaya tetap pada usaha pembuatan pakan ikan menggunakan azolla microphylla yang meliputi pembuatan bangunan dan pembelian alat pada tahun 2013 memerlukan biaya sebesar $\mathrm{Rp}$ 44.612.500, tahun $2014 \mathrm{Rp}$ 251.000 karena alat yang digunakan penyusutan alatnya 3 tahun bahkan lebih dari 3 tahun, sehingga pada tahun, dan tahun 2015 sebesar Rp 253.000. Total biaya tetap pada produksi pembuatan pakan ikan dengan azollzmicrophylla selama tiga tahun adalah sebesar Rp 45.116.500.

Biaya variabel pada pakan ikan dengan azollz microphylla selama tiga tahun yang meliputi pembelian bahan baku, biaya sarana produksi seperti bahan baku dan tenaga kerja dari tahun 2014 samapi dengan tahun 2015 biaya yang digunakan dari tahun 1 sampai dengan tahun ke 3 berbeda karena berpengaruh dari kenaikan dan penurunan harga bahan baku pada pembuatan pakan ikan. Berikut adalah komponen biaya variabel pada pembuatan pakan ikan dengan tambahan azolla microphylla di Desa Tegal Rejo adalah sebagai berikut :

Tabel 3. Biaya Variabel pada Usaha Pembuatan Pakan Ikan dengan Tambahan Azolla microphylla di Desa Tegal Rejo Kecamatan Belitang.

\begin{tabular}{llrrrr}
\hline & & \multicolumn{3}{c}{ Tahun } & \\
\cline { 3 - 5 } No & Biaya Operasional & \multicolumn{1}{c}{2013} & \multicolumn{1}{c}{2014} & \multicolumn{1}{c}{2015} & \multicolumn{1}{c}{ Jumlah } \\
\hline 1. & Dedak & 2.225 .000 & 1.625 .000 & 1.700 .000 & 5.550 .000 \\
2. & Bekatul & 4.450 .000 & 4.875 .000 & 5.100 .000 & 14.425 .000 \\
3. & Ikan Asin & 5.562 .500 & 4.875 .000 & 5.950 .000 & 16.387 .500 \\
4. & Azolla & 3.560 .000 & 3.250 .000 & 4.080 .000 & 10.890 .000 \\
5. & Karung & 445.000 & 536.250 & 612.000 & 1.593 .250 \\
6. & Tali Rafia & 178.000 & 130.000 & 136.000 & 444.000 \\
7. & Solar & 2.492 .000 & 2.600 .000 & 2.720 .000 & 7.812 .000 \\
8. & Tenaga Kerja & 8.900 .000 & 7.800 .000 & 9.520 .000 & 26.220 .000 \\
\hline \multicolumn{7}{l}{ Total Biaya Operasional } & 27.812 .500 & 25.691 .250 & 29.818 .000 & 83.321 .750 \\
\hline
\end{tabular}

Sumber: Olahan Data Primer, 2015. 
Berdasarkan tabel di atas biaya variabel usaha pembuatan pakan ikan dengan azolla microphylla di Desa Tegal Rejo Kecamatan Belitang Kabupaten OKU Timur dari pembelian dedak sampai dengan biaya tenaga kerja pada tahun 2014 sebesar Rp 27.812.500, tahun 2014 sebesar Rp 25.691.250 pada tahun 2015 permintaan pakan dari konsumen meningkat sehingga produksi pakan ikan meningkat dan biaya operasional yang dibutuhkan juga tinggi, dan biaya operasional tahun 2015 sebesar Rp 29.818.000 permintaan pakan stabil dari tahun 2014 sampai dengan tahun 2015 proses produksi pakan juga stabil dari 2013 sampai 2015. Jumlah biaya variabel pada usaha pembuatan pakan ikan selama 3 tahun dengan jumlah Rp 83.321.750.

Total biaya pada usaha pembuatan pakan ikan di Desa Tegal Rejo yang terdiri dari biaya tetap dan biaya variabel yang dikeluarkan oleh responden adalah sebagai berikut:

Tabel 4.Total Biaya Produksi pada Usaha pembuatan Pakan Ikan dengan

Tambahan Azolla microphylla di Desa Tegal Rejo Kabupaten OKU Timur.

\begin{tabular}{rrrrr}
\multirow{2}{N}{$\mathrm{o}$} & Uraian & \multicolumn{3}{c}{ Tahun } \\
\cline { 3 - 5 } & & 2013 & 2014 & \multicolumn{1}{c}{2015} \\
\hline \multirow{3}{*}{1} & Biaya & 44.612 .5 & & \\
& Tetap & 00 & 251.000 & 253.000 \\
& Biaya & & & \\
& Variab & 27.812 .5 & 25.691 .25 & 29.818 .0 \\
2 & el & 00 & 0 & 00 \\
\hline & & & & \\
& Jumlah & 72.425 .0 & 26.193 .25 & 30.324 .0 \\
& & 00 & 0 & 00 \\
\hline
\end{tabular}

Sumber: Olahan Data Primer, 2016.

Berdasarkan tabel di atas (tabel 4) dapat diketahui bahwa usaha pembuatan pakan ikan dengan tambahan azolla microphylla yang terdiri dari biaya tetap dan biaya v72.425.000ariabel pada tahun 2014 biaya produksi yang digunakan sebesar Rp 64.425.000, tahun 2015 adalah sebesar Rp 26.193.250, dan biaya produksi pada tahun 2015 adalah sebesar Rp 30.071.000.

\section{B. Rata-rata, Produksi, Harga Jual, Penerimaan dan Pendapatan Usaha Pembuatan Pakan Ikan dengan Tambahan Azolla microphylla.}

Usaha dikatakan menguntungkan apabila selisih antara penerimaan dengan pengeluarannya itu bernilai positif. Berikut adalah hasil produksi, harga jual, penerimaan, dan pendapatan responden pada usaha pembuatan pakan ikan dengan penambahan azolla microphylla di Desa Tegal Rejo Kecamatan Belitang Kabupaten OKU Timur dapat dilihat pada tabel berikut:

Tabel 5. Jumlah Produksi, Harga, Penerimaan, dan Pendapatan Usaha Pembuatan Pakan Ikan dengan Tambahan Azolla microphylla Tahun 2014-2015.

\begin{tabular}{llrr}
\hline No & Uraian & \multicolumn{1}{c}{ Tahun 201: } \\
\cline { 3 - 4 } & & \multicolumn{1}{c}{2014} & \multicolumn{1}{c}{2015} \\
\hline 1. & Produksi Pakan $\mathrm{Kg}$ & 9.790 & 7.150 \\
2. & Harga $(\mathrm{Rp} \mathrm{Kg})$ & 50.00 & 6.500 \\
3. & Penerimaan $(\mathrm{Rp})$ & 48.950 .000 & 46.475 .000 \\
4. & Biaya produksi $(\mathrm{Rp})$ & 72.425 .000 & 26.193 .250 \\
5. & Pendapatan $(\mathrm{Rp})$ & -23.475 .000 & 20.281 .750 \\
\hline
\end{tabular}

Sumber: Olahan Data Primer, 2015.

Berdasarkan tabel di atas hasil produksi pakan ikan dengan tambahan azolla microphylla dilakukan satu bulan 4-8 kali proses produksi penggilingan pakan ikan hanya pada Bulan Desember dan Bulan Januari dilakukan satu kali proses produksi karena pada bulan tersebut pelaku usaha sedang melaksanakan hari raya Natal sehingga proses produksi pakan ikan diliburkan. Produksi pakan ikan dengan tambahan azollamicxrophyla dilakukan responden selama 3 tahun dengan perolehan hasil produksi masingmasing pada tahun 2014 pelaku usaha memproduksi $9.790 \mathrm{~kg} /$ tahun dengan harga $\mathrm{Rp}$ 5000/kg dengan memberikan penerimaan sebesar $\mathrm{Rp}$ 48.950.000 dengan biaya produksi $\mathrm{Rp}$ 7.425.000, sehingga memberikan pendapatan sebesar Rp -23.475.000.

Pada tahun 2015 usaha pembuatan pakan ikan memproduksi $7.150 \mathrm{~kg} /$ tahun dengan harga jual Rp 6.500/kg. Penerimaan diperoleh pelaku usaha sebesar Rp 46.475.000, dengan penggunaan biaya produksi sebesar Rp 26.193.250.

\section{Analisis Kelayakan Usaha}

\section{Analisis NPV}

Net Present Value sering diterjemahkan sebagai nilai bersih sekarang. Perhitungan NPV dalam suatu penilaian investasi merupakan cara yang praktis untuk mengetahui apakah proyek menguntungkan atau tidak. Keuntungan dari suatu proyek adalah besarnya penerimaan dikurangi pembiayaan yang dikeluarkan. Dengan demikian, dapat dikatakan bahwa NPV adalah selisih antara Present Value dari arus Benefit dikurangi Present Value PV dari arus biaya (Soekartawi, 1996 dalam Shinta, 2011). Proyek yang memberikan keuntungan adalah proyek 
yang memberikan nilai positif atau NPV $>0$, artinya manfaat yang diterima proyek lebih besar dari semua biaya total yang dikeluarkan. Jika $\mathrm{NPV}=0$, berarti manfaat yang diperoleh hanya cukup untuk menutupi biaya total yang dikeluarkan. NPV < 0 , berarti rugi, biaya total yang dikeluarkan lebih besar dari manfaat yang diperoleh.

Tabel 6. Analisis Kelayakan Usaha Pembuatan Pakan Ikan Azolla microphylla.

\begin{tabular}{|c|c|c|c|c|}
\hline Biaya Manfaat & & Tahun & & Jumlah \\
\hline & 2013 & 2014 & 2015 & \\
\hline 1. Biaya Investasi & 44.612 .500 & 251.000 & 253.000 & 45.116 .500 \\
\hline 2. Biaya Operasional & 27.812 .500 & 25.691 .250 & 29.818 .000 & 83.321 .750 \\
\hline 3. Total Biaya & 72.425 .000 & 26.193 .250 & 30.324 .000 & 128.436 .250 \\
\hline \multicolumn{5}{|l|}{ 4. Kelayakan Usaha } \\
\hline NPV df $18 \%$ & & & & 16.867 .875 \\
\hline NPV (-) $43 \%$ & 1.77 & 1.34 & 1 & $\begin{array}{r}-127.80 \\
6\end{array}$ \\
\hline \multicolumn{5}{|l|}{ Compounding Factor } \\
\hline 18 & 1.39 & 1,18 & 1 & 4 \\
\hline PVR & 48.950 .000 & 46.475 .000 & 55.440 .000 & $\begin{array}{r}150.865 \\
000\end{array}$ \\
\hline PVC & 72.425 .000 & 26.193 .250 & 30.324 .000 & $\begin{array}{r}128.436 \\
.250\end{array}$ \\
\hline PVB & 23.475 .000 & 20.218 .750 & 25.116 .000 & $\begin{array}{r}22.428 . \\
750\end{array}$ \\
\hline Net $B C$ & & & & 1.5 \\
\hline IRR & & & & 31.8 \\
\hline
\end{tabular}

Sumber: Olahan Data Primer, 2015.

Berdasarkan tabel 6 di atas diperoleh nilai investasi usaha pembuatan pakan ikan dengan azollamicrophylla selama 3 tahun adalah sebesar Rp 37.116.500. Biaya operasional selama 3 tahun adalah sebanyak Rp 83.321.750, sehingga total biaya produksi dalam pembuatan pakan ikan dengan azolla sebesar Rp 127.934.250. Total penerimaan usaha pembuatan pakan ikan dengan azolla microphyla selama 3 tahun adalah sebesar Rp 150.865.000. Total pendapatan usaha pembuatan pakan ikan dengan azolla microphylla selama tiga tahun adalah sebesar Rp 22.930.750.

Hasil perthitungan NPV selama tiga tahun produksi pembuatan pakan ikan dengan tambahan azollamicrophylla di Desa Tegal Rejo dari tahun 2013 sampai dengan tahun 2015 dengan tingkat bunga $18 \%$ (NPV df 18\%) maka diperoleh nilai NPV sebesar Rp 16.867.875. Berdasarkan analisis diperoleh nilai NPV > 0 , maka usaha pembuatan pakan ikan dengan tambahan azolla microphylla di Desa Tegal Rejo menguntungkan dan layak secara finansial.

\section{Analisis IRR (Internal Rate of Return)}

IRR adalah nilai discountu rate (I) yang membuat NPV suatu proyek sama dengan nol atau dengan perkataan lain IRR menunjukkan present value (benefit) sama dengan present value (cost) Digunakan untuk mencai tingkat bunga yang menyamakan $\mathrm{Bt}$ pada nilai sekarang dengan $\mathrm{Ct}$ pada nilai sekarang di masa-masa mendatang.
Untuk mengetahui sejauh mana proyek memberikan keuntungan, digunakan analisis IRR. IRR dinyatakan dengan persen (\%) yang merupakan tolak ukur dari keberhasilan proyek (Shinta, 2011). Penggunaan Investasi akan layak jika diperoleh IRR yang persentasenya lebih besar dari tingkat suku bunga bank yang ditentukan, karena proyek berada dalam keadaan yang menguntungkan, demikian juga sebaliknya jika IRR lebih kesil dari tingkat suku bunga bank yang ditentukan, berarti proyek merugi dan tidak layak untuk dilaksanakan.

Berdasarkan hasil pembuatan pakan ikan dengan tambahan azolla microphylla asil perhitungan pada tabel 5 diperoleh nilai NPV positif (+) adalah sebesar Rp 16.867.875 nilai NPV negatif (-) terkecil dengan nilai interest $31,84 \%$ adalah sebesar Rp -127.806. Hasil perhitungan dengan menggunakan Compounding Factor 18\%, maka memperoleh nilai IRR pada usaha pembuatan pakan ikan di Desa Tegal Rejo adalah sebesar $31,89 \%$ yang berarti nilai IRR lebih besar dari nilai suku bunga bank pertahun SOCC (Social Opportunity Cost of Capital) sebesar 18\%. Hal ini menunjukan bahwa usaha pembuatan pakan ikan di Desa Tegal Rejo Kecamatan Belitang Kabupaten OKU Timur menguntungkan dan layak secara finansial dapat untuk dikembangkan.

\section{Analisis Net B/C}

Net Benefit Cost Ratio adalah penilaian yang dilakukan untuk melihat tingkat efisiensi penggunaan biaya berupa perbandingan jumlah nilai bersih sekarang yang positif dengan jumlah nilai bersih sekarang yang negatif, atau dengan kata lain $\mathrm{Net} \mathrm{B} / \mathrm{C}$ adalah perbandingan antara jumlah NPV positif dangan jumlah NPV negatif dan ini menunjukkan gambaran berapa kali lipat benefit akan kita peroleh dari cost yang kita keluarkan (Gray, 1997 dalam Shinta, 2011). Suatu proyek layak dan efisien untuk dilaksanakan jika nilai Net B/C > 1, yang berarti manfaat yang diperoleh lebih besar dari biaya yang dikeluarkan. Sebaliknya jika Net B/C < 1, berarti manfaat yang diperoleh tidak cukup untuk menutupi biaya yang dikeluarkan sehingga proyek tidak layak dan efisien untuk dilaksanakan.

Tabel 7. Analisis Net B/C Usaha Pembuatan Pakan Ikan Azollz microphylla.

\begin{tabular}{ccc}
\hline N & Tahun & \multicolumn{2}{c}{$\begin{array}{c}\text { Nilai Present Value } \\
\text { Benefit (PVB) }\end{array}$} \\
\hline 1 & 2013 & -32.686 .590 \\
. & & 23.932 .465
\end{tabular}


3

2015

\begin{tabular}{lr}
\hline Nilai Net B/C & 25.622 .000 \\
\hline Sumber: Olahan Data Primer, 2015. \\
Berdasarkan hasil perhitungan nilai Net \\
B/C adalah sebesar 1,5, nilai Net B/C > 0 berarti \\
usaha pembuatan pakan ikan di Desa Tegal Rejo \\
Kecamatan Belitang modal usaha yang \\
digunakan akan memperoleh keuntungan setelah \\
dikenakan bunga bank sebesar Rp 1,5 dari \\
penggunaan modal usaha pada pembuatan pakan \\
ikan dengan penambahan azolla microphyla \\
sehingga usaha pembuatan pakan ikan dengan \\
azolla microphylla menguntungkan dan layak \\
untuk dikembangkan.
\end{tabular}

\section{IV.KESIMPULAN DAN SARAN}

\section{A. Kesimpulan}

Berdasarnya hasil penelitian dan analisis yang telah dilakukan, maka dapat ditarik kesimpulan sebagai berikut:

1. Pada tahun 2014 pelaku usaha memproduksi $9.790 \mathrm{~kg} / \mathrm{tahun}$ dengan harga $\mathrm{Rp} 5000 / \mathrm{kg}$ dengan memberikan penerimaan sebesar $\mathrm{Rp}$ 48.950.000 dengan biaya produksi $\mathrm{Rp}$ 7.425.000, sehingga memberikan pendapatan sebesar Rp -23.475.000. Pada tahun 2015 usaha pembuatan pakan ikan memproduksi $7.150 \mathrm{~kg} /$ tahun dengan harga jual Rp 6.500/kg. Penerimaan diperoleh pelaku usaha sebesar Rp 46.475.000, dengan penggunaan biaya produksi sebesar Rp 26.193.250, sehingga memperoleh pendapatan sebesar Rp 20.281.750. Tahun 2015 pelaku usaha pembuatan pakan ikan dengan tambahan azollamicrophylla memproduksi $7.920 \mathrm{~kg} /$ tahun dengan harga jual $\mathrm{Rp} 7.000 / \mathrm{kg}$ maka penerimaan diperoleh sebesar Rp 55.440.000, penggunaan biaya produksi sebesar $\mathrm{Rp}$ 30.324.000 maka pendapatan diperoleh sebesar Rp 25.116.000.

2. Usaha pembuatan pakan ikan dengan tambahan azolla microphylla di Desa Tegal Rejo Kecamatan Belitang Kabupaten OKU Timur layak untuk dikembangkan. Dengan memenuhi kriteria nilai NPV Rp 16.867.875, nilai IRR sebesar $31,86 \%$, dan nilai Net B/C diperoleh 1,5.

\section{B. Saran}

Saran yang dapat diberikan dari hasil penelitian yang telah dilakukan adalah:

1. Pengembangan usaha pembuatan pakan ikan dengan penambahan azolla microphylla perlu diupayakan terus karena mempunyai prospek yang bagus pada usaha budidaya ikan.

2. Perlunya dukungan pemerintah dalam bentuk produksi pakan ikan agar dapat meningkatkan konsumsi pakan ikan dengan azolla microphylla.

\section{DAFTAR PUSTAKA}

Anonim. 2011. Usaha Budidaya Tanaman Azolla microphyla di Kolam. http://www.wirausahaimpian.com/2013/09/ usaha-budidaya-azolla-microphylla.html

Asminatun. 2010. Pembuatan Pakan Ikan Berdasarkan Konsep Protein Ideal yang Ramah Lingkungan. Jurnal UI Untuk Bangsa Seri Kesehatan, Sains, dan Teknologi, 1: 70- .

Dharmawan, B. 2013. Usaha Pembuatan Pakan Ikan Konsumsi. Pustaka Baru Press. Yogyakarta.

Djojosuwito, Soedijono, Azolla, Pertanian Organik dan Multiguna, Yokyakarta: Kanisius, 2000.

Emma, Z. 2006. Studi Pembuatan Pakan Ikan dari Campuran Ampas Tahu, Ampas Ikan, Darah Sapi Potong, dan Daun Keladi yang Disesuaikan dengan Standar Mutu Pakan Ikan. Jurnal Sains Kimia 10: 40-

Gusrina. 2005. Membuat Pakan Ikan. PT. Musi Perkasa Utama. Jakarta

Gunawan, RBG dan Bagus Harianto, Dongkrak Produksi Lele dengan Probiotik Organik. PT. Agro Media Pustaka. 2012.

Hanafie, R. 2010. Pengantar Ekonomi Pertanian. CV. Andi Offset. Yogyakarta.

Handajani, H. 2000. Peningkatan kadar protein tanaman Azolla microphylla dengan mikrosimbion Anabaena azollae dalam berbagai konsentrasi $N$ dan $P$ yang berbeda pada media tumbuh. Tesis. Program Pasca Sarjana. Bogor. 
Handajani, H. 2006. Pemanfaatan Tepung Azolla sebagai penyusun pakan ikan terhadap pertumbuhan dan daya cerna ikan Nila gift. Lembaga Penelitian UMM. Malang.

Hernanto, F. 2001. Ilmu-ilmu Usaha. Penebar Swadaya. Jakarta.

Masyamsir. 2001. Program Keahlian Budidaya Ikan. Departemen Pendidikan Nasional Proyek Pengembangan Sistem Dan Standar Pengelolaan SMK. Erlangga. Jakarta.

Rahardi.F. 2003.Mengubah Rintangan Menjadi Peluang Berinvestasi.PT. Agromedia Pustaka. Jakarta.

Rahim, A. dan Diah, R. 2007. Ekonomika Pertanian. Penebar Swadaya. Jakarta.

Santio, 2012. Kepala Dinas Perikanan dan Peternakan Kabupaten OKU Timur . http : //SRIPKO -OKUT-Budidaya Ikan// .com.

Sjarkowi, F dan Marwan, S. 2004. Menejemen Agribisnis. Baldad Grafiti Press Palembang

Sjarkowi, F. 2010. Menejemen Pembangunan Agribisnis. Baldad Grafiti Press Palembang

Sirakov, I. \& E. Ivancheva. 2008. Influence Of Stocking Density On The Growth Performance Of Rainbow Trout And Brown Trout Grown In Recirculation System. Bulgaria Journal of Agriculture Science, - .
Sukirno, Sadono. 2011. Ekonomi Mikro Teori Pengantar. PT Raja Grafindo Persada. Jakarta.

Soekartawi. 2001. Agribisnis Teori dan Aplikasinya. PT. Gravindo Persada. Jakarta

Soekartawi. 2011. Ilmu Usahatani dan Penelitian untuk Pengembangan Petani Kecil. Penerbit Universitas Indonesia. Jakarta.

Suratiyah, K. 2006. Ilmu Usaha Tani. Penebar Swadaya : Jakarta.

Kotler, P. 2002. Manajemen Pemasaran. Prenhallindo. Jakarta.

Nazir, Moh. 2011. Metode Penelitian. Ghalia Indonesia. Bogor.

Taken dan Asnawi, S. 2005. Teori Ekonomi Mikro. Departemen Ilmi-ilmu Sosial Ekonomi IPB.Bogor. 